\title{
ESSENCE OF INSECURITY OR CIVILIZATIONAL PORTRAYAL OF TRANSIENCE
}

\author{
Marek Adamkiewicz \\ Wojskowa Akademia Techniczna
}

Arnold Warchał ${ }^{1}$

Wojskowa Akademia Techniczna

\begin{abstract}
The article in a broad perspective presents the various proposition describing the explanation of human transience, and stigma of death, as the source of existential fear. The methodological approach adopted for the article, notices reflection on a subject in four plains of philosophy, sociology, psychology, but largely bioethics (and especially thanatology). The text touches upon the metaphysical concerns, in a sense that the human demise is considered as insecurity, mentally rooted in social representation of transience. Such a mode of reasoning is established understanding that the concept of a human corpse becomes a manifestation of an intelligible, through the evolution of life from the state of existence to nonexistence. Recognition of "deadness" as the natural order, seen as the paradox of human existence, persisted in the richness of thoughts, projects, and hopes. In opposition to this perception of life (or rather of impermanence), the authors take the position which excludes the passing away understood as a form of non-existence of consciousness. Views presented through this proposition rest on a fundament of contemporary researches of medicine (e.g., psychiatry, oncology, cardiology, or psychology). From this perspective, the article is a new proposition of a research that can be grounded in contemporary security studies.
\end{abstract}

Keywords: insecurity, death, sociology of security, philosophy, civilization, thanatology.

In consideration of its existential dimensions, the oddity of transience forces us to face interests of various and particular epistemological endeavors and explanations about the reality. This in turn calls for the corresponding interpretations of human capabilities and heterogeneous ability to understand life and its representations ${ }^{2}$. However the different pondering on a subject, since corresponding to the individual perceptions of phenomenon, its goals require discovery of an essence of transience rooted in being itself. Especially since nothing reminds us so forcefully, that our fate at the end is the fate of us all?

1 Co-author would like to thank professor Adamkiewicz for the opportunity of working on this project, and participating in knowledge, where main weight rests in researches of professor's expertise.

2 Q.v.: V. Messori, Wyzwanie wobec śmierci, transl. T. Jania i B. Zawada, Wydawnictwo „m”, Kraków 1995; T. Wołynowicz, Mój ostatni zachód słońca... A co potem?, Nasza Przyszłość, Bydgoszcz 1998.

3 Q.v.: Polish discussion on this problem in M. Hempoliński's, Miłość i śmierć w perspektywie filozoficznej, [in:] Miłość i śmierć, K. Imieliński (edit.), Wydawnictwo SPAR, Warszawa 1991; A. Nowicka- 
Some researchers believe that the disclosure of the content of the concept of transience is wrongfully identified with word "dying", wrongfully since the latter is both a process and an existential awareness, which is a conscious state of the impending finality of life ${ }^{4}$. Yet, the source of transiency - death, has a wide semantic spread where the content is dominated by the cultural, philosophical, and theological values, plus of course the medical and physiological, though to the lesser extent ${ }^{5}$. However, such an assessment is unsanctioned by the existing knowledge in medicine, as well as psychology, since in the process of passing away there are phenomena (e.g. suffering, pain, or stress), which become in the most subtle sense infused into the structure of human existence, and thus impact the perception and its reception. Obviously, the research on the mystery of the transiency belongs to particular existential human structure and perception within various disciplines, correlated with knowledge that its essence is intertwined with the perepetum mobile of death. And the works of such authors Elizabeth Kübler-Ross ${ }^{6}$, Anselm Strauss i Barney Glaser ${ }^{7}$, Herman Feifel ${ }^{8}$, Davida Sudnow ${ }^{9}$ and John Hinton ${ }^{10}$, considered to be pioneering in the fields of thanatology ${ }^{11}$, initiated in the sixties of the XX century great swell of social interest focused on the problem of transience bewitched by the processes of death and dying.

Aforementioned theoretical motivations inspired, in the West, a call for the reform and change in the care approach towards the terminal cases. It also allowed Cicely Saunders ${ }^{12}$ in England, to open the first London hospice. In France, general Benedetti from the Medical Academy of Paris has founded the Institute of Thanatology researching the ways and means of palliative care for terminally ill, and Maurice Marois created the Institute of Life, bringing together the researches on dying and alternation of life ${ }^{13}$. In Poland - in the seventies of the last century - the subject

Jeżowa, Pieśni czasu i śmierci, Towarzystwo Naukowe KUL, Lublin 1992; R. Cantalamess, Siostra śmierć, transl. K. Homa, Wydawnictwo WAM Księża Jezuici, Warszawa 1994.

4 Cf: P. Bortkieiwicz, Tanatologia. Zarys problematyki moralnej, Uniwersytet im. Adama Mickiewicza, Poznań 2000, p. 9.

${ }^{5}$ Cf.: M. Wańczowski, Księga żałoby i śmierci, Nakład Autora, Opole 1993, p. 379.

6 Q.v.: E. Kübler-Ross, Rozmowy o śmierci i umieraniu, przekł. I. Dolżak-Nowicka, Pax, Warszawa 1979.

7 Q.v.: B. Glaser, A, Strauss, Awareness of Dying, Aldine, Chicago 1965; B. Glaser, A, Strauss, A Time for Dying, Aldine, Chicago 1968.

8 Q.v.: H. Feifel (edit.), The Meaning of Death, McGraw Hill, New York 1959.

9 Q.v: D. Sudnow, Passing On. The Social Organization of Dying, Prentice Hall Inc., Englewood Cliffs NJ 1967.

10 Q.v.: J. Hinton, Dying, Penguin Books, Middlesex (England) 1967.

11 V: A. Ostrowska, Śmierć w doświadczeniu jednostki i społeczeństwa, Wydawnictwo IFiS PAN, Warszawa 1997, p. 15.

12 Q.v.: C. Saunders, Care of the Dying, The Macmillan Company, London 1967.

${ }^{13}$ Cf.: Ch. Chabanis, Śmierć, kres czy początek, przekł. A. D. Tuszyńska, Instytut Wydawniczy PAX, Warszawa 1987, p. 27. 
of transience, separate of philosophical reflection and close to empirical approach, was undertaken by Tadeusz Kielanowski ${ }^{14}$, Magdalena Sokołowska ${ }^{15}$ i Bogdan Kamiński ${ }^{16}$. The number of practical problems at that time dimmed the theoretical interests in this phenomenon. Nonetheless, with time number of publications on thanatology by native authors has risen and systematically improved current categorical knowledge about psychosocial functioning of an individual confronting the passage of life. Those studies exploring intricacies of evanescence allow for extracting the methodological planes, of which its anthropological outlook on final boundary reveals existential forethought on dying.

Evanescence of life touches every human and every being on this planet. It is the natural law describing every biological existence. Moreover, this is the exact reason why the inevitability of death requires constant interest. Hardly any conscious and rational being would renounce its weight on deliberation about life. Furthermore, the universality of the transient nature and experience of life and its circumstances leads to permanent contact with death. More importantly, assimilation of notion of dying is redeemed by widely represented in humans' fear of the end ${ }^{17}$. Inevitability of death and short-lived span of life, especially in the face of numerous concerns and sufferings across the world leads some to doubts and ponderings about the meaninglessness of existence and others to see the antinomy in states of none life. ${ }^{18}$ Those who believe in possibility of existence without death as the end, seem to have an easier task of overcoming the disheartening fear of own disappearance, even if there are also those who seem to be peaceful in face of this biological determinant. According to this last perception about reality, its manifestation is seen through hidden and fragmentary continuum in a relay of generations of beings, where the main goal is successive progress and the development of technological and moral human capabilities. Within this belief, there is a constant tendency of people trying to trick death, to prolong youth and escape old age through measures leading to a long life. The succor of this desire correlates with development of medicine sup-

14 Q.v.: T. Kielanowski, Rozmyślania o przemijaniu, Wiedza Powszechna, Warszawa 1980.

15 Q.v.. M. Sokołowska, Socjologia medycyny, Wiedza Powszechna, Warszawa 1980.

${ }^{16}$ Q.v.: B. Kamiński, Lekarz wobec śmierci, (w:) Człowiek wobec śmierci, KAW, Warszawa 1976. Za: A. Ostrowska, Śmierć w doświadczeniu jednostki i społeczeństwa, op. cit., p. 15.

17 This is the main theme of most works on human death. Cf.: A. Toynbee, Człowiek wobec śmierci, przekł. D. Petchs, PIW, Warszawa 1973; Ph. Aries, Człowiek i śmierć, przekł. E. Bąkowska, PIW, Warszawa 1989; Antropologia śmierci. Myśl francuska, wybór i przekł. S. Cichowicz i J. M. Godzimirski, Wydawnictwo Naukowe PWN, Warszawa 1993; J. Brehant, Thanatos. Chory i lekarz w obliczu śmierci, przekł. K. Sudolska, Wydawnictwo Ancher, Warszawa 1993.; P. Bortkiewicz, Tanatologia. Zarys problematyki moralnej, Uniwersytet im. A. Mickiewicza, Poznań 2000.

18 Q.v.: R. Kastenbaum, Po tamtej stronie życia, przekł. R. Nowakowski, Diogenes, Warszawa 1998; H Holzer, Tamten świat, przekł. E. Maciejewska, J \& BF, Warszawa 1998; R. A. Moody, W stronę światła, przekł. S. Studniarz, Limbus, Bydgoszcz 1992; N. Randall, Życie po śmierci, przekł. D. Bakalarz, Studio Emka, Warszawa 1996. 
ported by engineering, but at the same time presents us with the moral dilemmas (dilemmas of genetics, eugenics or cloning), delaying the hypothetical possibility of victory over death. Obviously, the successes of medicine cannot overcome the constant fear dying. This is, according to the philosophers, a leading or elementary motive of human attachment to religion, and the oldest and primary source of human kinship with God ${ }^{19}$.

\section{The cultural substance and overcoming the terror of dying}

According to Bertrand Russell, the fear of transience and especially of dying is quiet possibly the main and constant danger for the human psychic seeking the sense of existence, however the task escapes our ability of rational thinking ${ }^{20}$. Such a view is still one dimensional, since looking for God only motivated by the fear of dying nonetheless makes clinging to life an only sense of living ${ }^{21}$. Yet, the opposite strongly rooted cultural tradition of the knightly ethos in Japan is proving that not fear but the contempt of death, maybe a source of refined sentiment and civilizational differences ${ }^{22}$. After all, based on this notion animistic Shintoism, worshiping the souls of ancestors as the living beings, rationalizes phenomenon of transience as the confirmation of life. In this outlook, death is not intermittent, but it is life, as we know it ${ }^{23}$. No matter what the provenience of an outlook on transience, the religious stand on the issue is for the most part the innermost cultural experience of in descriptions of the characteristics of life itself ${ }^{24}$. This seems to be confirmed by Fr. Andrzej Zwoliński's interpretation of a central point of various discussions where the fact of transient nature of existence is brought down to two enlightening answers to the questions of: what awaits us after dying and how to define the category of eternity ${ }^{25}$.

When it comes to potentiality of future being, after the crossing of a boundary of existence, two options are considered. The first assumes that when life is extinguished

\footnotetext{
19 V.: T. Kotarbiński, L. Infeld, B. Russell, Religia i ja, Książka i Wiedza, Warszawa 1981.

${ }^{20}$ Cf.: Ibidem, p. 76.

${ }^{21}$ Cf.: L. Ferry, Człowiek - Bóg czyli o sensie życia, przekł. A. i H. Miś, PIW, Warszawa 1996, s. 7-13.

22 Cf.: H. Ishikawa, Miłość i śmierć w Japonii, [in:] Miłość i śmierć, pod red. K. Imielińskiego, Wydawnictwo SPAR, Warszawa 1991, pp. 164-166.

${ }^{23}$ Cf.: Kojiki, czyli ksiegga dawnych wydarzeń, przekł. i wstęp W. Kotarbiński, PIW, Warszawa 1986.

24 Cf: ks. S. Kowalczyk, Postawy człowieka wobec śmierci, „Colloquium Salutis” 1975, $7^{\text {th }}$ y, pp. 297-324.

${ }^{25}$ Cf.: A. Zwoliński, Życie... ile razy?, Wydawnictwo WAM, Kraków 1998, s. 6. Book by A. Zwoliński is an excellent monograph on reincarnation, beginning with the Hindu culture (Vedas, Brahmanism, Hinduism, Jainism, Buddhism), then the idea metempsychosis in the European pre-Christian beliefs and influence and Christian interpretation of the ancient views about "transmigration of souls", up to the views in contemporary philosophy, theosophy, anthroposophy, New Age, as well as social consequences of acceptance. Cf.: A. Dominirski, Reinkarnacja. Szkic monograficzny, Oficyna Wydawnicza Zetpress, Warszawa 1989.
} 
a person plunges into the nothingness and "melts" into death forever. This vision is disseminated by atheism. Alternatively in the other notion, the human essence remains and is incorporated into the cosmic, transcendental sphere of creation, based on the religious understanding of existence ${ }^{26}$. However, at the acceptance of the hypothesis on eternal continuum of being, there appear two more visions of immortality, persistent in the religious and social traditions. One considers eternity as a "return" to temporal life through reincarnation ${ }^{27}$, and the other considers it as a goal of the eternal existence, what is typical in Christianity, Islam, and Judaism. ${ }^{28}$

Given the persistence of both antinomies of transience, the more popular is not the materialistic but the transcendental formation. This can be rationalized by a tendency of mental processes to accept those views, such as the religious, promoting through its normative systems a stand focused on help to overcome the fear of dying, putting its custody on human effort to find the answers about the unknown. In such contextual settings it is worth presenting the view, distancing himself from religion, Tadeusz Kotarbiński, who said once: "It's sad to understand that own atheistic stand is alien for those traditional views, widely accepted by my own society of the dominating worldview and spiritual style of thinking of its members. There is a consolation however in the fact that religion is also promoting those values, which in principle, according to the best moral interpreters and followers, also lead to the same selfless ethics and earnest caregiving upon the reflection of an atheist about the essence of conscience" 29 .

In all the religious traditions, dying had its metaphysical and spiritual meaning, even if very often considered evil and anguish ${ }^{30}$. In predeceasing the religious view mythology, we find self-sustained conception of eternity and eternally young humans. Still, this later ends with a heavy price to be set for misconduct against harmony - the godly ideal creation of order and perfection. This "disgrace" was illuminated by various explanations. Some explained it with death of the mythical idol (whose power emanated also on the people) and was a consequence of war between gods and men. In other views, it was the result of recklessness and irresponsibility on behalf of transcendental beings or the men, sometimes also considered as the penalty for disobedience of gods ${ }^{31}$. Such alternations are already exhibited in the oldest

${ }^{26}$ Cf.: Ibidem, p. 7. Some atheist and agnostics also accepted this stand, for example the Marxist philosopher Ernst Bloch, and the representative of Frankfurt school of philosophy: Teodor Adorno and Max Horkhaimer (cf.: M. Adamkiewicz, Zagadnienie śmierci w bioetyce, Wydawnictwo WAT, Warszawa 2002, p. 61).

27 Cf.: S. Rinpoche, Tybetańska księga życia i umierania, A. Kozieł, Wydawnictwo EM, Warszawa 1996; Buddyjska wizja śmierci i umierania, choice of J. Sieradzan and R. Palusiński, Wydawnictwo T.T, Kraków 1997.

${ }^{28}$ Cf.: A. Zwoliński, Życie... ile razy?, op. cit., p. 7.

29 T. Kotarbiński et all, Religia i ja, op. cit., p. 18.

30 Vide discussion of John Bowker in: Sens śmierci, op. cit., PIW, Warszawa 1996.

${ }^{31}$ Q.v.: N. Smart, The Religious Experience of Mankind, wyd. III, Charles Scribner`s Sons, New York 1984. 
Mesopotamian epos of Gilgamesh, telling the story of the hero who accidently loses the branches of an eternal life, by allowing a snake to steal it. It was a gift from the gods given to the patriarch Utnapisztim (Mesopotamian Noe), now gone. It is the entire human race being disgraced by mistake of Gilgamesh and because of it, was sentenced to transience in temporal time of existence. However, its necessity leads to conclusion that even if death is a pitiful and a sorrowful state nature (like a bad luck) it is because of the natural order and harmony itself. It is of the necessity. Morally, in conclusion of the epos, it teaches its readers that transience has to be accepted as an integral life cycle and life should be therefore cherished as long as possible ${ }^{32}$. We can observe that the motif of a malicious being standing against human search for eternal life is present in different believes across the globe in various forms, in separated from each other cultures. In the African traditions for example, chameleon or a goat plays the role of a demon. In the North American Indians folklore, the coyote brings in the death into life of humans ${ }^{33}$.

The fall of humans, as the loss of flawlessness of creation and its eternal life in consequence of disobedience against the holy authority is fully expressed in the Judeo-Christian tradition. According to the Bible, the first humans - Adam and Eve - were thrown out of paradise (the garden of God), and lost the chance of eating the fruits from "the tree of life" that may have the essence of eternity for everyone. Nevertheless, it was the lawless behavior and questions of personal will that forced the transience upon them ${ }^{34}$. This story determined the entire tradition of Western view on death, considered as a sanction of negative proportions, however not a cause and effect relation, but order evolving from nature of change. In this context - according to Fr. Ireneusz Mroczkowski - the theological sense of transience is summed up not as the biological consequence but punishment of sin. This punishment touches only the godless people. Whereas, the biological death is almost considered through a happy sense of deliverance, with positive functions for those able to read its message. Subsequently, transience is tragic only for the "not so wise", believing that the end is the final passage of existence. Only those should fear death that "belong to devil" and live in "worldly sins"35.

The nature of the transient being did not come out of harmony, but from distortion of law established by God. Hence, even in contemporary Christian tradition

\footnotetext{
32 Q.v.: N. K. Sandars, Gilgamesz, trans. by. R. Stiller, PIW, Warszawa 1980.

33 Cf.: J. R. Lewis, Życie po śmierci. Encyklopedia wierzeń, mitów, zjawisk, trans. by J. Korpanty, Świat Książki, Warszawa 1999, p. 338-339.

${ }^{34}$ Cf.: I. Mroczkowski, Zło igrzech. Studium filozoficzno-teologiczne, Wydawnictwo KUL, Lublin 2000, s. 254-259.

35 Cf.: Ibidem, p. 255-256.
} 
the transience is considered as belonging to a human holistically ${ }^{36}$. It is because biologically "one doesn't know" why a multicellular form of life expire, specifically the human life, the explanation of the important of cultural suggestions become obvious. The religious (and bioethical) rationale for this commonality of the outcome, initiated by moral catastrophe of human being, becomes the voice of many ${ }^{37}$. In this motif, our domestic view interprets the anthropological aspects of transience falling within the set touching on the field of cultural bioethics ${ }^{38}$. Differently, the Americans consider the subject of historical, civilizational and social context of ethical problems interesting only if it throws facts on modern considerations advancing biology and medicine. In this respect the reflection of thanatology links determinants between some cultural formation and its system of values with a social acceptance that allocates the means of research in view of established traditional moral inclinations ${ }^{39}$. Mieczysław Gałuszka and Kazimierz Szewczyk believe however, that the contemporary civilization is dependent on biomedical mythology and reflects a state of permanent fear of dying and suspicious of the art of medicine, mesmerizing with its potentiality of overcoming "every" disease of life ${ }^{40}$. Promise to root out afflictions leading to transience partially influences a scientific hope of ability to fight death and overcoming, even if not fully, the fear present in final agony. In this sense, the bio-cultural ethics as a subject regulating, above the individual, social, and civilizational field of biomedical determinants, describes the human patterns of human behaviors, analyzing the influence of innovations in changes of populations. In other words, the domestic scientific interest of research about the transience (maybe also the religious one) should include in study of biomedicine the state of changes influencing the culture, that lead to categorical establishment of knowledge about the individual moral choices ${ }^{41}$.

\section{Transience in view of the civilizational transformation}

The cultural changes occurring due to successes in biomedical sciences were particularly deliberated upon by Philippe Aries, who came to conclusion that progress in practices of medicine radically changed the social attitude in regards to dying, thus changing and distancing it away from the inevitable. The patterns of development in medicine

\footnotetext{
${ }^{36}$ K. Rahner, H. Vorgrimler, Mały słownik teologiczny, transl. T. Mieszkowski and P. Pachciarek, Instytut Wydawniczy PAX, Warszawa 1987, p. 450.

37 Cf.: Ibidem, p. 451

38 Cf.: M. Gałuszka, K. Szewczyk, Bioetyka kulturowa wobec zagadnienia śmierci, (in:) Umierać bez lęku. Wstęp do bioetyki kulturowej, M. Gałuszka and K. Szewczyk (edits.), Wydawnictwo Naukowe PWN, Warszawa - Łódź 1996, pp. 7-13.

39 Cf.: PWN leksykon. Filozofia, Wydawnictwo Naukowe PWN, Warszawa 2000, p. 62.

40 Cf.: M. Gałuszka, K. Szewczyk, Bioetyka kulturowa wobec zagadnienia śmierci, op. cit., p. 9.

${ }^{41}$ Cf.: Ibidem, p. 11
} 
influenced the cultural changes over time and have "tamed" 42 the idea of death, from a "brutish" ${ }^{43}$ phenomenon that in its extreme form was "awry" 44 in face of dramatic and temporal human presence, into an act of loneliness and departure from life. Even if at the beginning of the XXth century, the individual death influenced attitudes and behaviors by creating a dimension of reflection about the meaning of death for the entire Western culture (Latin and Protestant), after 1914 in the most urbanized and technically advanced countries the new model of "brutish" participation in twilight of someone else's life became apparent in an "awry" and "unfamiliar" perception of passing 45 .

Once ago, the death was a recipient event for the entire community and a content of a social group that reacted spontaneously through the customs of mourning on collectively expressed pain, though a tragic but judged a necessary twist of fate. Everyone was not only dying publically, but the death of each was an apostolical event for the entire community. It was not only the death of an individual but also of the communal consciousness represented by the person "going away". Throughout the millennia, not all different variants, overlapping in attitudes towards death, changed the fundamental picture dependent on a stable relationship between the transience of a unit and a loss for society. Usually, death and its surroundings, that is passing away, was always both a public and at the same time individual act.

Edgar Morin has stated that there is a close correlation between the subjective relationship to death and objective knowledge, that is, the degree of understanding of being, and of its individuality, had been measured by severity of specific life in face of importance for local collective loss ${ }^{46}$. Some studies have shown that in the behavior of primeval peoples, in their physiology and phenomenon of corporeal life, there is rooted and shared with the others, the collective awareness of life and death. Laughter, tears, lamentation, prayer, contained in the ritual are the same as physiological reactions, like a "body language", releasing mental tension in times of grief. Shared need for funeral ritual have suggested purpose, or was initiating collectivity of the group trying to abolish physical and moral maladies caused by the death of a member ${ }^{47}$. However, the once important comportment that enhanced the communal aspect of death gradually is passing into oblivion, since - as was described by Vladimir Yankele-

\footnotetext{
42 Q.v: Ph. Aries, Człowiek i śmierć, przekł. E. Bąkowska, PIW, Warszawa 1989, p. 19-292.

${ }^{43}$ Q.v.: Ibidem, pp. 293-548.

44 Q.v. Ibidem, pp. 549-590.

45 Cf.: Ibidem, pp. 549-550.

${ }^{46}$ Q.v.: E. Morin, Antropologia śmierci, [w:] Antropologia śmierci. Myśl francuska, wybór i przekł. S. Cichowicz, J.M. Godzimirski, Wydawnictwo Naukowe PWN, Warszawa 1993, pp. 77-157.

47 Cf.: M. Mauss, Związki psychologii i socjologii w sferze faktów i w sferze badań, [in:] Socjologia i antropologia, transl. by J. Szacki, PWN, Warszawa 1973, p. 429; also, Idea śmierci wpajana przez zbiorowośc i jej wplyw na ciało jednostki (Australia, Nowa Zelandia), [in:] Socjologia i antropologia, op. cit., p. 462. Q.v.: K. Turek, Ludowe zwyczaje, obrzędy i pieśni pogrzebowe na Górnym Ślasku, Wydawnictwo Uniwersytetu Śląskiego, Katowice 1993.
} 
vitch - meta-empirical tragedy of the inevitable by nature impermanence is currently being replaced with a gap of "my" (own) death versus "your" (someone else's) dying48. A while ago, it was not the case. „My" death was not so far away from "your” death, since both brought together unquestioned social belief in the mysterious act of passage to the "other" side, and its hidden existential dimension.

Nowadays, the death has become a common enough phenomenon and can be observed almost exclusively as a statistical, mass media, and judicial fact, or little important biological event. It was stripped of its uniqueness because of its commonality and quantity in presentations within the technological mass culture environment. This implies that it was stripped of the mysterious character or fairy tail description. It is concrete in a sense of being normal and familiar, seldom mysterious, however serious, real, ineluctable and personal. The miracle can be mysterious, but death does not fall in that category ${ }^{49}$. The act of passing away is no longer, for a social group, a time of contemplation about the individual sense of grief. It became superficial yet frightful. Jan Sarna in Poland is stressing this notion analyzing views on dying by some of the philosopher, since they are intellectually predestined and adept in possible comprehension of the terminal phases of life. Unpredictably he drew attention to the tendency of thinkers to escape from difficulties on this issue ${ }^{50}$. Those wisdom seekers who openly talk about dying in reference to facts recognition very often are disapproved ${ }^{51}$. Nevertheless, the life is a dialog with death. This presents death, alone true for everyone, as the - seldom-questioned - guarantee of justice for all in this world. Demise and death are not relativistic in any circumstances, but inevitable and therefore absolute.

The demise of a human being appears mind-boggling, since, as is understood in the last century by Ludwig Wittgenstein, "the life is not changing, but ending" 52. Hence, another thinker - Andrè Frossard states: "the only way to avoid deaths is simply not to exist" 53 . Accordingly, the disappearance of life a fact beyond purely medical or biological phenomena, people in all cultures and societies care about

${ }^{48}$ Cf:. V. Yankelevitch, Tajemnica śmierci i zjawisko śmierci, [in:] Antropologia śmierci. Myśl francuska, op. cit, pp. 41-64.

49 Cf.: Ibidem, pp. 45-46.

50 Cf.: J. Sarna, Człowiek i filozofia, Oficyna Wydawnicza „Ston 2”, Kielce 2000, p. 122; an example is given there from the life of $\mathrm{F}$. Nietschego who in his book The Will to power, considers it in in one of the pragraphs about the death with such title, but doesn't write any more on the issue, besides giving it a title. This was also repeated by L.Wittgenstein in his Tractatus logico-philosophicus (Polish trans. by B. Wolniewicz, Wydawnictwo Naukowe PWN, Warszawa 1997). In his view of metaphysics, he is silent on matters, where one "cannot say anything". According to him, the death is not of life, so one does not live through it.

51 In: J. Sarna, Człowiek i filozofia, op. cit., p. 122.

52 L. Wittgenstein w Tractatus logico-philosophicus, op. cit., p. 431.

${ }^{53}$ A. Frossard, 36 dowodów na istnienie diabła, transl. by Z. Ławrynowicz, W drodze, Poznań 1996, p. 70 
keeping life and mourn its final loss ${ }^{54}$. Dialogue with the gradual and inevitable loss of existence appending our entire life is the hallmark of our being, and in stages of existence and its demise creates cultural artifacts (including the funerals), plus in mythological, later religious and philosophical descriptions. Noticing that the religion and philosophy justifies also the dimensions of mortality, we must however look at it through a prism of death. Life and death are one of two inseparable elements and opposing values in a constant struggle of ever-changing world. It is not without reason that the August Comte defined society as a whole of the living and of the dead, and with reference to this Martin Heidegger added that people participating "in being" contrary to voluntarily form suspended in any culture, create temporary personality within consciousness of drama and ill fate ${ }^{55}$.

The source of anxiety in face of demise for any civilization, of different times, was not the passing away itself, but the real possibility of annihilation of existence. Dying can be gracious, unless it implies that it is absolutely final in view of our temporality within temporality of space, understood as the absolutely finality, what cannot be reasoned with and cannot be accepted especially if it applies to nature as a whole. Even in cultures built on apology of post-mortem life (e.g. in ancient Egypt), its dimension and character is rooted in belief about continuum beyond the bodily realm of being. Hence, the appropriate religious practices and specific philosophy referring to the netherworld, also of course, the scientific technics for preparation of dead body (mummification) for immortality (through final conception of mortal being). Not being able to comprehend the relationship between being and non-being, of the two conflicting dimensions of life, would lead to transfer of the hope for eternal living through materialization of bodily essences. This hope, as was believed, was accomplished by creation of the infinite biological form, the mummy. However, such aspirations are neither naïve nor futile, because from the point of view of the human psyche, everything that involves a lifetime of hardships, the complexity of existence, plans, etc., made sense; terminated in agony deprivation of life was considered therefore senseless. The life of agony becomes deprivation. Since life has a meaning for us, its antinomy must be of this world. Therefore, the continuousness after death may have its justification, what religions are stubbornly seeking. It is the dramatic struggle for endurance against certain death connects

\footnotetext{
54 In Poland, the thanatolgy is considered, among the others, by works of: A. Nowicka-Jeżowa, Sarmaci i śmierć, Wydawnictwo Naukowe PWN, Warszawa 1992; B. Rok, Zagadnienie śmierci w kulturze Rzeczypospolitej czasów saskich, Wydawnictwo Uniwersytetu Wrocławskiego, Wrocław 1991; K. Ziemba, Jan Kochanowski jako poeta egzystencji, Towarzystwo „Ogród Ksią," Warszawa 1994; A. Lubaszewska, Młodopolska antropologia śmierci i literacki świat wartości, Wydawnictwo Uniwersytetu Jagiellońskiego, Kraków 1995. Q.v.: E. Kizik, Śmierć w mieście hanzeatyckim w XVI-XVII wieku, Wydawnictwo Uniwersytetu Gdańskiego, Gdańsk 1998; B. M. Neuman, Modlitwy za zmarlych, „Grapio”, Warszawa 1997.

55 Cf.: J. Sarna, Człowiek i filozofia, op. cit., p. 125.
} 
us to a dilemma of vitality against senseless destruction. Such a view is present in words of the astrophysicist John Taylor, when he writes: "None of us wants to die, but death is part of us, whether we like it or not; "None of us wants to die, but death is with us, whether we like it or not; unfortunately, we don't yet know how to avoid it. All beings begin to die soon after birth; none can escape that" 56 .

\section{The twentieth century interpretation of dying.}

In a face of urbanization and technological alterations of the XX c., the perception of transience has also transformed. This transformation can be summarized by notion that there is no time for pondering on the events that captivate what is currently more important, the vital and hedonistic presence, even if temporary. It is obvious that death and its consequences was "abolished" by the human admiration of human technical abilities to overcome the physical and measureable obstacles of nature, and thus promoted the opportunity to enjoy the benefits presented by the industrial culture. If it cannot be avoided, than it has to be moved away from present field of view, forgotten and detained from social validation. This is how a new model of transience evolved in ambience of death. Philippe Aries has called it "the opposite", "negative" to all that preceded its persistence in traditional understanding of a plain and obvious facts of constantly changing matter ${ }^{57}$.

With the exception of individual deaths, transience is almost banished from society. This explains why in contemporary cities one can seldom tell that whether here and there, eschatological events are taking place, in view of the living, with little awareness and interest to most, because modernization and its technological advancement deceptively promotes a removal of those from peoples' attention. "The olden silver-black caravan - writes Aries - was transformed into a simple gray limousine, and does not cause any suspicion when it moves through streets. Community will not stop in its tracks: when one person perishes, it does not spoil its own continuity. The city is always alive and unconscious of individual deaths ${ }^{58}$.

The changes in perception of death made its impact on conventional mourning customs. Even if in the middle of the XX c. death grief could be observed in almost ritualistic social behaviors and particular style (crepe, black veils, purples markings of profanity, special badges, etc.), not long after - such experiences have become almost embarrassing, and long-term external manifestations of mourning became unusual in the surroundings of personal grief. Transformation process was the consequence of the cultural changes originating in the XIX century in face of

\footnotetext{
56 J. Taylor, Czarne dziury: koniec wszechświata?, transl. M. Kalinowski and J. Piesiak, PIW, Warszawa 1987, p. 87.

57 Cf.: Ph. Aries, Człowiek i śmierć, op. cit., p. 550.

58 Ibidem
} 
technological progress. Over time, along with its acceleration, and development of medicine, when demise materializing in dying moved from home to hospitals, the distance between the agony of a person and its observance by other people stretched. Source of this can be seen not only in technological progress, but also and especially in transformation of social surroundings, where already in the XIX century, maybe even a hundred years before it, in the name of emotional attachment to a dying person process of dying was disconnected from effective consciousness about it. This game of appearances that included everyone resulted in lies about the real condition of health. It settled for good in the relations between the participants on both sides of the event - of the death and the disappearance of life ${ }^{59}$. A lie of love became a weapon of defense for a person pressed by own emotional character, against events deepening individual fear and sorrow. Protection of a dying person takes place with a help of illusion of survival. It serves a happy notion of communication possibility until the final moments of life. Yet, it takes away freedom and pathos of mutual connection in the final hours. However, before "the lie of death" became a constant for interpersonal acceptance in relation to transience - what was especially pointed by $\mathrm{Ph}$. Aries - "[love] thanks to its beauty, made possible to promote closest links between the one passing away, and those who stayed: the last connection to God and - or - close one was a great privilege of dying ${ }^{60}$.

Let us remember though the intimacy and beauty of the last flickering flame of life was still burdened by ugly disease. This in some ways explains the need of disguising of this ugliness before dying and its surroundings, forcing the transfer of a person to a hospital. In the moment when last traditional means of defense against death (available at home) were losing its potency, the medicine along with its hospital equipment and group of professional, cool-headed staff was evolving into commune for the dying, presenting itself with knowledge and everything necessary, except emotional states, of course. However, the hospital in one sense terminates the possibility of lying about dying, but in the other, by giving patients hope of life, underlines conspiracy around death. A sense of distinctiveness of the person and its identity before the law in reference to freedom of one's own demise has been accorded by the clinics as, induced by the thoughtfulness of the family. Currently we observe this mode, alienating for the individual beings, being replaced by another routine, a combination of family home warmth, and more empathic hospital care. Today, the practical expression of this "not estranging" philosophy of transience and palliative care is a hospice. The pioneer to this model was David Kessler, who as one of the first nurses who founded in 1984 in the U.S. (Los Angeles) the Organization of Progressive Nursing Services, dedicated to the needs of terminally ill patients

\footnotetext{
${ }^{59}$ Cf.: Ibidem, pp. 551-552.

60 Ibidem, p. 601.
} 
(mainly with AIDS and cancer). Promoted by Kessler hospice care covered treatments, activities, behavioral and procedural methods addressed exclusively to the final moment of passing, of those whose existence have been left to their own fate, and who have been left out in the time of their greatest need. The aim of this initiative of empathetic initiative was granting the dying a help impossible to obtain in hospitals or private clinics. As a result, the objectives of Kessler led to - admittedly superficial but the only one so far - transformation of cold and impersonal experience of death into an experience full of love, relief, and understanding on the part of caregivers. The hospice in this concept also has to prepare the family and friends of the dying for this experience, which is no longer a tragic, horrible, lonely, and more painful than necessary ${ }^{61}$.

The idea of hospice was from an outset propagated by Elisabeth Kübler-Ross and practiced extensively by Mather Theresa of Calcutta. She addressed and postulated in life of care homes the list of rights of dying ${ }^{62}$. Those would be: 1) treating the dying the same as the living person; 2) keeping the faith of everyone participating in process of death, regardless of the circumstances; 3 ) caring by helpers up keeping the hope, regardless of the circumstances; 4) expressing in own way of feelings and emotions associated with death; 5) participating of the dying in decisions about their care; 6) caretaking by persons that are compassionate, sensitive and competent, who are able to understand the individual needs; 7) waiting for the continuing medical care, even if the "treatment" changes to "relief of pain"; 8) receiving by the patients and their loved ones honest and complete answers to all the questions; 9) creating any conditions necessary for exploration by dying of the human spirituality; 10) relieving patients from physical pain; 11) expressing in their own way of feelings and emotions associated with pain; 12) participation of children in the death of their parents, siblings, grandmothers and grandparents; 13) understanding the dying process; 14) submission to death; 15) dying in peace and with dignity; 16) dying surrounded by fellows dying (not allowing dying in loneliness); and finally 17) expecting that after death sanctity of their bodies will be respected ${ }^{63}$. Therefore, the functioning of the hospices rests upon respect of the fundamental rights of those passing away, and this is currently the statutory interpretation by a state of the rules, not only for the dying but also living ${ }^{64}$. I

${ }^{61}$ D. Kessler describes those experiences in his book - Śmierć jest częścią życia. O prawo do godnego umierania, transl. E. Czerwińska, Świat Książki, Warszawa 1999.

62 Q.v.: Mother Teresa, Prosta droga, collected by L. Vardey, transl. R. Grzybowska and J. Węcławik SVD, Wydawnictwo Verbinum, Warszawa 1996, pp. 89-140

63 These laws are in force in the entire world hospice movement. Cf.: D. Kessler, Śmierć jest czesścia zycia..., op. cit., p. 8.

${ }^{64}$ Cf.: Ibidem, p. 9. 
The civilized societies have developed so far two conceptions of transience, tolerated by technological and consumptive cultures. The popular first admit its powerlessness and hence it does not recognize it as a phenomenon worth deeper reflection. The second, aristocratic, accepts the loos of existence but in accordance with the possibilities of modern customs ${ }^{65}$.

The popular conception treats transience, and especially dying, as a type of blemish, which cannot be prevented, what in consequence may turn into cowardly and shameful behavior. This is the reason for spread of hospice philosophy. The concealment of facts relating to loss of life prevails in daily life and brings human activities faking interest in mortality, which in colloquial reception sets the illusion about absence of death in life. The lack of contemplation about death leads to silence in cultural representation of transience, what is typical in contemporary societies (Western). The reflection on human demise occurs only in instances of death of the rich and famous, or when it is an effect of spectacular tragedies, catastrophes, wars or terrorism. Unfortunately, with the exception of mass deaths (for example the tragic in consequence terrorist attacks in the USA on 9/11 in 2001) transience does not belong to existentially dramatic meaning but is considered incidental for ego and an ordinary phenomenon of life. Few interested parties, touching only people dying and their loved ones, usually share events associated with mortality. The position of the popular notions brings temporal existence and the passing away to the level at which neither the unit nor the community have the strength or the will to recognize the existence of their own (and inevitable) end ${ }^{66}$.

On the other hand, the aristocratic notion is a consequence of curiosity common for some of the anthropologists, philosophers, psychologists, and sociologists that wish - instead of evicting death from human consciousness - to civilize it by acceptance of its necessity, in holistic consideration of our existence. This notion explains death not as something to be ashamed of, but as an exceptional manifestation of nature's wisdom and in many cases as graciousness underlined with dialectical order of evolutionary cause-effect harmony. Although scholars do not allude to old folk (e.g. animistic) wisdom accepting death naturally, they are far away from paradigms describing transience as something awry of social harmony, since it is understood that necessity for generational exchange strengthens the culture, improving it in the evolutionary way for the following generations. This notion stems from the fact that, as the anthropologists believe, reconciliation of death and happiness is the main goal of scientific endeavor. According to this, death should not only be discrete but a peaceful and dignified departure from a compassionate, understanding, caring and not angered or indignant because of transience, society. Stating it differently, in

${ }^{65}$ Cf.: Ph. Aries, Człowiek i śmierć, op. cit., pp. 602-603.

${ }^{66}$ Cf.: Ibidem, s. 602. 
aristocratic notion the idea of thanatology is apparent a belief that in commonality of death we can consider it as an average biological process, that has no real effect on our mortal life. It is considered a process of life, not the process of death as envisioned through pain, grief, resentment or any negative emotions. Life may have a price label of death, but it is still for life and in accordance with life, where everything is an immanence of nature's endeavors. Within this there is a human culture evolving and a human being able to accept own demise without fear, pain or grief ${ }^{67}$.

\section{The corpse as a substantive interpretation of transience}

Uncommon in the anthropological literature analyzing death, a permanent cultural artifact, is a stand of Louis-Vincent Thomas, for whom most important aspect hitting our imagination is death's substantive result, namely "the corps" 68 . According to him, this visible aspect - the dead body - was the only empirical possibility of seeing the end of life. In this view, the idea of death apparent in philosophical and theological discussion is an abstraction arising not by accident but created purposely out of human fear of dying. It simply moves away the cemetery vision, the real picture, and end of existence. Clearly, the most concrete substratum of such idea is that of a corps, not as a phenomenon but material in any dimension and for all practical means, an example of non-existence, as an effect of transience. Although all the societies are trying to reconcile with its mystery, nonetheless the corpse abolishes notion of cultural, social, and existential order, preventing the human beings from coming to peace, while thinking about the transcendental future. In view of this, the concept of death is connected to process of decomposition of a biologically structured body, experienced in nature both as "braking down" the life and "accumulation" of matter used for another life. This "break down" is a social fact, since the corpse of a deceased is moved away from a social gathering, and the mourners are stopped from participation in daily chores. At the same time, "accumulation" is a fragmented economy of life, which in decay moves the substantive atoms and molecules necessary to survival of the needy and existing plants and animals, as the substance of energy ${ }^{69}$. The new expression of protoplasm, however including the particles of a now defunct unit of life, and in biological sense immortalizing it, for the conscious being it is a rather problematic perspective ${ }^{70}$. For the conscious being in fact, the constancy, individuality of own forms and over all the real duration of being, not just being an organic raw material for nature's future growth, is a goal.

67 Cf.: Ibidem, s. 603.

${ }^{68}$ Q.f.: L-V. Thomas, Trup. Od biologii do antropologii, transl. K. Kocjan, Wydawnictwo Łódzkie, Łódź 1991.

${ }^{69}$ Cf.: Ibidem, pp. 21-26.

70 Cf.: Ibidem, pp. 38-43. 
Nonetheless, the natural dimension of death implies coexistence of living entities with the immense accumulation of corpses, which also play a role of source for the historically established rituals. Those in turn, through variety of funeral rites, form anthropological accumulation of life's artifacts fraternized with transience and inevitable death, presented with purpose of explanation of biological dimensions and with significance for social meaning ${ }^{71}$.

Death ritualized and symbolized in many ways in unison with normative dogmas and liturgies, discontinues dying. Farewell of the deceased in form of its corpse, is keeping its entity alive for posterity of man still alive. In this colloquial sense, but persisting in culture through different values, those who are still alive, are not alive totally, and those who are dead, are not "very" dead ${ }^{72}$. The corpse determined by physical and chemical processes is at the same time a fundament of faith and a cult of life overall (what influences the funeral rituals) and conjures on supernatural essences (making its impact on transcendental interpretation as such) ${ }^{73}$.

Discussion of this type belongs to elder versions of narrative, which clashes with contemporary studies in reference to consciousness and essence of human transience, visible in studies of different scientists from various disciplines. The polemics with that paradigm defending the only materialistic view on human nature is exemplified by stances of the, oncologist dr. Jeffrey Long ${ }^{74}$; professor of behavioral studies and psychiatry dr. Bruce Greyson ${ }^{75}$ of the University of Virginia in Charlottesville; professor of counseling and psychology dr. Janice Miner Holden ${ }^{76}$ of the University of Northern Texas in Denton; professor of psychology from the University of Connecticut in Mansfield dr. Keneth Ring77; neurobiologist from the University of Arizona in Tucson dr. Mario Beauregard ${ }^{78}$; or psychologist Isabelle Raynauld ${ }^{79}$. However, when we study changes in attitudes towards human beings beyond the problem of a corpse, we owe a lot to Dutch cardiologist Pim van Lommel, who

71 Cf: Ibidem, pp. 5-7.

72 Cf.: J. Maisonneuve, Rytuały dawne i współczesne, transl. M. Mroczek, Gdańskie Wydawnictwo Psychologiczne, Gdańsk 1995, pp. 37-38.

73 Cf.: L-V. Thomas, Trup. Od biologii do antropologii, op. cit., pp. 9-11; 44-49.

${ }^{74}$ Q.v.: Jeffrey Long, P., Evidence of the Afterlife: The Science of Near-Death Experience, Harper One, New York 2010.

${ }^{75}$ Q.v.: Bruce Greyson, Consistency of Near-Death Experience account over two decades: Are reports embellished over time? "Resuscitation" (2007) 73, pp. 407-411.

${ }^{76}$ Q.v.: J. M. Holden, Bruce Greyson, Debbie James, The handbook of Near-Death Experiences: Thirty Years Investigation, Harper One, New York 2009

77 Q.v.: K. Ring, Life at death. Ascientific investigation of the near-death experience, Coward McCann and Geoghenan, New York 1980. K .Ring, Sh. Cooper, Mindsight: (Mind sight?) Near-Death and Out-of-Body Experiences in the Blind: A study of Apparent Eyeless Vision, UC Press, Mansfield 2008

78 Q.v.: M. Beauregard, D. O 'Leary, The Spiritual Brain: A Neuroscientists Case for Existence of the Soul, Harper One, New York 2009 or M. Beauregard, Brain Wars, Harper One, New York 2012.

${ }^{79}$ Isabelle Raynauld, The Mystical Brain, LAP Lambert Academic Publishing, Saarbrucken 2006. 
studied the phenomenon NDE (Near Death Experience: the clinical deaths states) and came up with the new hypothesis of consciousness, that is stemming not from, a very common notion of the material nature of being (at least in reference to human beings) ${ }^{80}$. It is thanks to him and a team of other Dutch scientists, including dr. Ruud van Wees, dr. Vincent Meyers and dr. Ingrid Elfferich, who published in 2001 in a prestigious scientific periodical "The Lancet" an article titled Near-death experience in patients with cardiac arrest: a prospective study in Netherlands ${ }^{81}$ that we can discuss the problem of dying in the new light. This study was showing research continuous since 1986 research. Besides those of near death experiences observations since 1969, also the examinations done in 10 Dutch hospitals, based on relations of 334 patients with cardiac arrests. In a compatible researches done in the last decade by the Americans, Jeffrey Long and Paul Perry have shown 1600 verified cases of experiences in clinical death states ${ }^{82}$. Additionally, the case of NDE was also shown from the patient's perspective, and described by Anita Moorjani in her famous book titled Dying To Be $\mathrm{Me}^{83}$. Referring to the relations from the boundary line of life and death, which are continual for the last 30 years but are still a taboo for science, what is reflective of the "death problem" in the Western culture, in general.

The phenomenon of NDE proves considerations that the human demise is a necessity, a mistake. This repeals the common in academic studies (positivistic approach) dogma, also present and protected in the tenets of some monotheistic religions, not allowing the possibility of conscious existence beyond biochemical or its electrophysiological possibility. According to evidences based on scientific studies, the consciousness is not a product or byproduct of brain processes reflecting the objective reality, but is a consciousness recognizing a being of self. Hence, based on NDE occurrences inference can be made that consciousness is a continuum and does not "belong" to death. Such thesis is revolutionary in a sense of "Copernican revolution" as a shift of a worldviews about human demise, changing those perspectives, that were so far determined by Judaic, Christian and Islamic points of view, yet scientifically not proven with experimental approach. The new approach experimentally suggests altered point of departure, where dimension of human life is possibly dualistic, without the body (corpse) consciousness is still a being (a mind or a soul).

${ }^{80}$ Such researches, of the scientists from different fields - from psychology to quantum physics, were presented by Pim van Lommel in his book, Wieczna świadomość. Nukowa wizja „Życia po życiu”, transl. Małgorzata Woźniak-Diederen, Wyd. ArtVitae, Warszawa 2010.

81 „The Lancet” 2001, Dec 15358 (9298): 2039-45.

82 Q.v.: J. Long, P. Perry, Evidence of the Afterlife: The Science of Near-Death Experience, op. cit.

83 The Polish version of the book: A. Moorjani, Umrzeć by stać się sobą, Studio Astropsychologii, Białystok 2013. 
In accordance to experiments done in a period of over thirty years, the 15 million Americans, 3 million 300 thousands Germans, 2 million French, have experienced the NED, what implies that, in researches done by P. van Lommel, $18 \%$ of the population goes through identical states, when brain does not function. The characteristics of this state are almost identical for all. In the first phase, NDE recollection is from the moment of unconsciousness, where there is a remembrance of medical personnel activities during the resuscitation, providing cardiopulmonary assistance. Every person remembering the state of NDE would consciously (almost with clearness of mind) observe the events. Even more importantly, the central element of experiencing death is feeling of bliss, peace, and happiness, since at that moment there is a total reduction of pain and trauma induced by suffering illness or fear of dying. Particularly compelling in every state of NDE is its final effect, that results in an expression of personal moral transformation, change of attitude (openness) towards the others, empathy, compassion, understanding and even indulgence. The last one specifically may refer to indulgence towards the skepticism and critics of the NDE, when discussing experience with others who doubt it, and rejects belief that consciousness may function without the brain. Nonetheless, the skepticism is valid since the NDE still cannot be explained (paradigmatically) in reference to contemporary scientific categories, (paradigmatically) tuned to experiential needs. On the other hand, those who survived the NDE consider the skeptics and their criticism as a manifestation of an insular behavior and obstinacy of the uninitiated skeptics unaware of example from deep experience of the survivors. Moreover, this is the reason why the skeptics chose the corporal explanation, observing the corpse.

Culturally, the corpse is treated by multidimensional perspective, since being an organic and passive object; it becomes a subject of ideology (religious and political). The other times it is manipulated (as a material for empirical researches - medical and biological), is also glorified (as seen through memoiristics of the famous historical personas), or happens to be sometimes a sacral prop (the relic). The body rot can be, at the same time seen pitiful and despised, or adored, what rests on need for symbolic imperative. The treatment of the corpse rests on communal need, where symbolically death was considered meaningless, or was underlined. This is why in literature, or art, the dead is presented in a contradictory manner, one time as a creepy carrion, and the other time as a fascinating and idealized subject of the sublime (this is illustrated by the funerary splendor).

The cultural differences continually determine definitions of the dead body. In arts the corpse can be presented in a disgusting and irritating, pathetic and reprehensible fashion, or as pristine and pure (e.g. white skeleton), respectful and even loved subject. The perception of the deceased thus depends on the ratio of specific communal thinking about fate of a man, which polarizes the debate about life, neutralizing or emphasizing the absurdity of death. However, such a discourse 
is not considering the corpse from the perspective of ownership, but as an excuse (mythological, iconographical, literary, mass media means) of taking it be the biological or social, or both, norm ${ }^{84}$. This is why depending on imaginary ideas, the language of description, the circumstances surrounding it (fear, grief, stereotypes), its phenomenon sometimes may be seen to be fascinating, or esthetical (so called the beauty of death) or against phantasms may give its shallow or deeper meaning. The dead body as an object of antinomy can become a source of empowerment, which triggers an aggression or revenge (expressions such as the desecration of corpses), or the beginning of worship (e.g. for a fallen hero or Saint), or hate (of a tyrant or traitor). The deceased may also become an object and treated as garbage (this applies to the bodies of people socially damned and castrated), as the raw material (body remains being used for commercial purposes) and an item of profitable circulation or used for the purpose of science (e.g. by archeology) ${ }^{85}$.

The corpse, as remain of human being - depending on cultural norms - has also its rights. The existing regulations for the protection of the deceased, however, are formulated to save progeny from harm they may suffer, when their dead are treated without respect. In the traditional societies where common law coincides with religious beliefs, the funeral rights are the essence of obligations ${ }^{86}$. This is supposed to determine the security of the living. If the burial rights are not done properly, the deceased could become dangerous for the community ${ }^{87}$. Since ancient times the obligation to bury dead bodies had a civil dimension. In modern Western societies this right was upheld, though given a different dimension of rationality. It was considered that the dead is the subject of veneration and worship due to its previous persona and the value of family and social life that the person represented. In legislature, it was underlined that the body remains are inseparable from that of a person, which implies that the principle of freedom to justify citizen's right in reference to the conditions of disposal of own body, when dead, have to be up kept. The corpse cannot be considered an item for sale, or made available for teaching purposes or scientific research, without the prior approval of the person concerned. The family has the right to decide only if the dead has not given any consent to use of the remains after death. The similar case applies to the rights of property inheritance. It

${ }_{84}$ Cf.: Ibidem, pp. 52-64.

85 Cf.: Ibidem, pp. 100-105.

86 Cf.:.Z. Staszczak, Obrzęd a obyczaj, PWN, Warszawa - Poznań 1985, p. 98-108; q.v. also R. Benedict, Wzory kultury, przekł. J. Prokopiuk, teksty poetyckie Z. Kierszys, PWN, Warszawa 1966; A. Michalak, Tradycje i współczesność polskiej obrzędowości pogrzebowej, Wydawnictwo TKKŚ, Łódź 1987; J. S. Bystroń, Dzieje obyczajów w dawnej Polsce. Wiek XVI-XVIII, T. 2, PIW, Warszawa 1976.

87 Por. np. B. Malinowski, Życie seksualne dzikich w Pótnocno-Zachodniej Melanezji, [w:] ibidem, Dzieła, T. 2, PWN, Warszawa 1980, pp. 274-278. 
is the moral and legal obligation to fulfill the last wishes of the dying about material goods and soma.

Simply stated, the body of the deceased is considered an integral part of a free and responsible subject, which imposes duty of respect for the deceased. The law is constructed in a way that is useful for the living. The living may seek relief from fear of potential aggression and favor the abolition of the guilt surrounding possibility of misappropriation of respect for a human being, even after death. Therefore, the custom and legislation does not tolerate a situation in which the dead is denied or prevented from being serviced by appropriate ritual ministry. This is because the collective honoring of deceased illustrates the formal attitude towards death in general. The fulfillment of the expected attention for the final rights of dead is a reflection of concern for the living in the similar situation. Explicitly, all the burial rights show attitude in potentiality of one's own demise ${ }^{88}$. This is where the symbolism, ceremonies of remembrances are metaphorically conjoining body with a person as a full being. In the final account, it is the thought about the living person that matters. The body is only an excuse for possibly egoistical nature of human beings anticipating own burial in an appropriate way. Acceptance of this value, value of the "cemetery rights", implicates among the others, also the acceptance of a person as the entity of self. Louis-Vincent Thomas suggests following: "In our positivistic culture characterized by individualism, it is rather a stubborn worship of the deceased by close ones, which allows up keeping the delusion of presence that is already an absence in becoming. For those who are not personally engaged and who can keep appropriate distance from own fear - in order to ascend towards plateau of own rationality - the corpse is only a scientifically described biological phenomenon. On the other side, in the eyes of the anthropologists, all the indicators of religious, magical, aesthetic or ostentatious values in reference to the corpse, prove that it is mostly the matter of the living 89 .

\section{Conclusion}

The contemporary mass culture, most strongly influenced by mass media, especially electronic, presents pretty to the eye and easy to comprehend intellectual blend of views presenting transience simplistically, as the common episode of daily life of the modern world ${ }^{90}$. The occurrence of death, both on the individual and on the mass scale, is nothing but unceremonious information similar to sport events, rock concert,

\footnotetext{
88 Cf. e.g. G. Mandelbaum, Social Uses of Funeral Rites, [w:] The Meaning of Death, H. Feifel (edit.), McGraw-Hill, New York - Toronto - London 1959, p. 198.

${ }^{89}$ L-V. Thomas, Trup. Od biologii do antropologii, op. cit., p. 120.

90 This phenomenon is described in: A. Ostrowska, Kultura masowa. Krytyka i obrona, PWN, Warszawa 1980.
} 
or political event. Its mass media value grows if it grabs the attention of a public with sensational story that shakes community in a way that stops it form noticing other television, radio or press news. Transience became a product subjected to the laws of the market in same fashion as any other pop culture commodity for sale. The "spectacles" of death also accommodate marketization with brutality and rape, in the movies, video games, novels, and thrillers making death the subject of an entertainment. In this last convention the contemplation and lack of reflection on human transience disappears. Association of death with life is moved away from human beings and makes it an abstraction opposing the human existence, as if unnatural. The significance of death can be important only so far, as it presents its reality on the grounds of a mass culture proposition. As a result, it is (and especially death) the subject of ludic manipulation and an artifact of publicized carefree entertainment. Here, the presence of transience is manifested as a contempt for human life and requires a suitable preset manipulation of abolishing the reflection on the transience ${ }^{91}$.

The indifference shaped this way is followed by own escape from the vision of own instability, and therefore, modern Western culture is rather a comfort entanglement in worldly, human matters, rather than the relief of in face of approaching transience. After all, the life of Americans or Europeans is organized to force their focus on what is temporal, the ad-hoc consumerism, and pleasure of her and now. Immortality if it is compatible with the current rationalism is verified by senses and experience horrified by visions of transience, but not of bloody brutality visible through life as shown on TV and other places. The facts of real (not artificial for the sake of entertainment) death of family members, friends and acquaintances in proximity, not to mention the real individual death, are considered tragic and devastating for life's order, therefore senseless and fatal. Contemporary hedonism cannot accept that perspective, and unable to cope with its potency pushes it away as far as possible. This is the reason why the sociologists emphasize that current medias focus of "death as a show" emerging through civilizational processes, what influences the families in social reception and educational practices ${ }^{92}$. In the alienating and hostile for the individual surroundings, the upcoming finality brings drama and despair for people orphaned by contemporary culture. In such legacy, life becomes the real tragedy. It is not a part of any life scenario. It surprises people who are not prepared. The end of life of close ones sometimes ruins the entire life of those who have to face it. Next to it, the media presents the message of death as a show and death as an unfortunate accident destroying activity of people in emulation (for commercial reasons) and a quest for success. Transience for the Western worldview is not an expression of necessity and a link of uninterrupted by nothingness evolution

91 Q.v.: Ibidem, pp. 297, 302.

92 Q.v:. M. Ogryzko-Wiewiórowska, Rodzina i śmierć, Wydawnictwo UMCS, Lublin 1994, pp. 28-29. 
of consciousness, but manifestation of randomness and irrationality of life, that in scientist and based on it colloquial opinion transforms the integral stage of human life into a hostile twist of fate.

\section{BIBLIOGRAPHY}

[1] Antropologia śmierci. Myśl francuska, choice and transl. S. Cichowicz i J.M. Godzimirski, Wydawnictwo Naukowe PWN, Warszawa 1993.

[2] Aries Ph., Człowiek i śmierć, przekł. E. Bąkowska, PIW, Warszawa 1989.

[3] Beauregard M., Brain Wars, Harper One, New York 2012.

[4] Beauregard M., O'Leary M.D., The Spiritual Brain: A Neuroscientists Case for Existence of the Soul, Harper One, New York 2009.

[5] Benedict R., Wzory kultury, transl. J. Prokopiuk, teksty poetyckie Z. Kierszys, PWN, Warszawa 1966.

[6] BortKieiwicz P., Tanatologia. Zarys problematyki moralnej, Uniwersytet im. Adama Mickiewicza, Poznań 2000.

[7] BowKer J., Sens śmierci, transl. J. Łoziński, PIW, Warszawa 1996.

[8] BRehant J., Thanatos. Chory i lekarz w obliczu śmierci, transl. K. Sudolska, Wydawnictwo Ancher, Warszawa 1993.

[9] Buddyjska wizja śmierci i umierania, choice of J. Sieradzana i R. Palusińskiego, Wydawnictwo T.T, Kraków 1997.

[10] Brstroń J.S., Dzieje obyczajów w dawnej Polsce. Wiek XVI-XVIII, T. 2, PIW, Warszawa 1976.

[11] Cantalamessa R., Siostra śmierć, transl. K. Homa, Wydawnictwo WAM Księża Jezuici, Warszawa 1994.

[12] Chabanis CH., Śmierć, kres czy początek, przekł. A. D. Tuszyńska, Instytut Wydawniczy PAX, Warszawa 1987.

[13] Dominirski A., Reinkarnacja. Szkic monograficzny, Oficyna Wydawnicza Zetpress, Warszawa 1989.

[14] Feifel H. [edit.], The Meaning of Death, McGraw Hill, New York 1959.

[15] Ferry L., Człowiek - Bóg czyli o sensie życia, przekł. A. and H. Miś, PIW, Warszawa 1996.

[16] Frossard A., 36 dowodów na istnienie diabła, transl by. Z. Ławrynowicz, W drodze, Poznań 1996.

[17] Ga£UszKa M., SzewCzyK K., Bioetyka kulturowa wobec zagadnienia śmierci, [in:] Umierać bez lęku. Wstęp do bioetyki kulturowej, edited by M. Gałuszka and K. Szewczyka, Wydawnictwo Naukowe PWN, Warszawa - Łódź 1996.

[18] Glaser B., Strauss A., A Time for Dying, Aldine, Chicago 1968.

[19] Glaser B., Strauss A., Awareness of Dying, Aldine, Chicago 1965. 
[20] Greyson B., Consistency of Near-Death Experience account over two decades: Are reports embellished over time? "Resuscitation" (2007) 73.

[21] Hempoliński M., Miłość i śmierć w perspektywie filozoficznej, [w:] Miłość i śmierć, edited by. K. Imieliński, Wydawnictwo SPAR, Warszawa 1991.

[22] Hinton J., Dying, Penguin Books, Middlesex (England) 1967.

[23] Holden J. M., Greyson B., James D., The handbook of Near-Death Experiences: Thirty Years Investigation, Harper One, New York 2009.

[24] Holzer H., Tamten świat, transl. E. Maciejewska, J\&BF, Warszawa 1998.

[25] Ishikawa H., Miłość i śmierć w Japonii, [in:] Miłość i śmierć, edited by K. Imieliński, Wydawnictwo SPAR, Warszawa 1991.

[26] KAMı́́sкi B., Lekarz wobec śmierci, [in:] Człowiek wobec śmierci, KAW, Warszawa 1976.

[27] Kastenbaum R., Po tamtej stronie życia, transl. R. Nowakowski, Diogenes, Warszawa 1998.

[28] Kessler D., Śmierć jest częścia życia. O prawo do godnego umierania, transl. E. Czerwińska, Świat Książki, Warszawa 1999.

[29] Kielanowski T., Rozmyślania o przemijaniu, Wiedza Powszechna, Warszawa 1980.

[30] Kızıк E., Śmierć w mieście hanzeatyckim w XVI-XVII wieku, Wydawnictwo Uniwersytetu Gdańskiego, Gdańsk 1998.

[31] Kojiki, czyli ksiega dawnych wydarzeń, transl. and introduction W. Kotarbiński, PIW, Warszawa 1986.

[32] Kotarbiński T., Infeld L., Russell B., Religia i ja, Książka i Wiedza, Warszawa 1981.

[33] Kowalczy S., Postawy człowieka wobec śmierci, „Colloquium Salutis” 1975, 7th y.

[34] KüBler-Ross E., Rozmowy o śmierci i umieraniu, transl. I. Dolżak-Nowicka, Pax, Warszawa 1979.

[35] Lewis J.R., Życie po śmierci. Encyklopedia wierzeń, mitów, zjawisk, transl. J. Korpanty, Świat Książki, Warszawa 1999.

[36] Lommel van P., Wieczna świadomość. Nukowa wizja „Życia po życiu”, transl. Małgorzata Woźniak-Diederen, Wyd. ArtVitae, Warszawa 2010.

[37] Long J., Perry P., Evidence of the Afterlife: The Science of Near-Death Experience, Harper One, New York 2010.

[38] Lubaszewska A., Młodopolska antropologia śmierci i literacki świat wartości, Wydawnictwo Uniwersytetu Jagiellońskiego, Kraków 1995.

[39] Maisonneuve J., Rytuały dawne i współczesne, przekł. M. Mroczek, Gdańskie Wydawnictwo Psychologiczne, Gdańsk 1995.

[40] Malinowski B., Życie seksualne dzikich w Północno-Zachodniej Melanezji, [w:] Tenże, Dzieła, t. 2, PWN, Warszawa 1980.

[41] Mandelbaum G., Social Uses of Funeral Rites, [w:] The Meaning of Death, pod red. H. Feifel, McGraw-Hill, New York - Toronto - London 1959.

[42] Matka Teresa, Prosta droga, zebrała L. Vardey, przekł. R. Grzybowska i J. Węcławik SVD, Wydawnictwo Verbinum, Warszawa 1996. 
[43] Mauss M., Idea śmierci wpajana przez zbiorowość i jej wpływ na ciało jednostki (Australia, Nowa Zelandia), [w:] Socjologia i antropologia, przekł. J. Szacki, PWN, Warszawa 1973.

[44] Mauss M., Związki psychologii i socjologii w sferze faktów i w sferze badań, [in:] Socjologia $i$ antropologia, przekł. J. Szacki, PWN, Warszawa 1973.

[45] Messori V., Wyzwanie wobec śmierci, przekł. T. Jania i B. Zawada, Wydawnictwo „m”, Kraków 1995.

[46] MichalaK A., Tradycje i współczesność polskiej obrzędowości pogrzebowej, Wydawnictwo TKKŚ, Łódź 1987.

[47] Moody R.A., W stronę światła, transl. S. Studniarz, Limbus, Bydgoszcz 1992.

[48] Moorjani A., Umrzeć by stać się sobą, Studio Astropsychologii, Białystok 2013.

[49] Morin E., Antropologia śmierci, [in:] Antropologia śmierci. Myśl francuska, wybór i przekł. S. Cichowicz, J. M. Godzimirski, Wydawnictwo Naukowe PWN, Warszawa 1993.

[50] Mroczкowski I., Zło i grzech. Studium filozoficzno-teologiczne, Wydawnictwo KUL, Lublin 2000.

[51] Neuman B.M., Modlitwy za zmarłych, „Grapio”, Warszawa 1997

[52] NowickA-Jeżowa A., Pieśni czasu i śmierci, Towarzystwo Naukowe KUL, Lublin 1992.

[53] NowICKA-Jeżowa A., Sarmaci i śmierć, Wydawnictwo Naukowe PWN, Warszawa 1992.

[54] Ogryzko-Wiewiórowska M., Rodzina i śmierć, Wydawnictwo UMCS, Lublin 1994.

[55] Ostrowska A., Kultura masowa. Krytyka i obrona, PWN, Warszawa 1980.

[56] Ostrowska A., Śmierć w doświadczeniu jednostki i społeczeństwa, Wydawnictwo IFiS PAN, Warszawa 1997.

[57] PWN leksykon. Filozofia, Wydawnictwo Naukowe PWN, Warszawa 2000.

[58] Rahner K., Vorgrimler H., Mały słownik teologiczny, transl. T. Mieszkowski i P. Pachciarek, Instytut Wydawniczy PAX, Warszawa 1987.

[59] Randall N., Życie po śmierci, przekł. D. Bakalarz, Studio Emka, Warszawa 1996.

[6o] Raynauld I., The Mystical Brain, LAP Lambert Academic Publishing, Saarbrucken 2006.

[61] Ring K., CoOper SH., Mindsight: (Mind sight?) Near-Death and Out-of-Body Experiences in the Blind: A study of Apparent Eyeless Vision, UC Press, Mansfield 2008.

[62] RING K., Life at death. Ascientific investigation of the near-death experience, Coward McCann and Geoghenan, New York 1980.

[63] Rinpoche S., Tybetańska księga życia i umierania, A. Kozieł, Wydawnictwo EM, Warszawa 1996.

[64] Rok B., Zagadnienie śmierci w kulturze Rzeczypospolitej czasów saskich, Wydawnictwo Uniwersytetu Wrocławskiego, Wrocław 1991.

[65] Sandars N.K., Gilgamesz, przekł. R. Stiller, PIW, Warszawa 1980.

[66] SARNA J., Człowiek i filozofia, Oficyna Wydawnicza „Ston 2”, Kielce 2000.

[67] SAunders C., Care of the Dying, The Macmillan Company, London 1967. 
[68] Smart N., The Religious Experience of Mankind, wyd. III, Charles Scribner's Sons, New York 1984.

[69] Sокоєошsка M., Socjologia medycyny, Wiedza Powszechna, Warszawa 1980.

[7o] Staszczak Z., Obrzęd a obyczaj, PWN, Warszawa - Poznań 1985.

[71] Sudnow D., Passing On. The Social Organization of Dying, Prentice Hall Inc., Englewood Cliffs NJ 1967.

[72] TAYlor J., Czarne dziury: koniec wszechświata?, transl. M. Kalinowski i J. Piesiak, PIW, Warszawa 1987.

[73] Thomas L-V., Trup. Od biologii do antropologii, transl. K. Kocjan, Wydawnictwo Łódzkie, Łódź 1991.

[74] Toynbee A., Człowiek wobec śmierci, przekł. D. Petchs, PIW, Warszawa 1973.

[75] Turek K., Ludowe zwyczaje, obrzędy i pieśni pogrzebowe na Górnym Śląsku, Wydawnictwo Uniwersytetu Śląskiego, Katowice 1993.

[76] Wańczowski M., Księga żałoby i śmierci, Nakład Autora, Opole 1993.

[77] Wittgenstein L., Tractatus logico-philosophicus, transl. B. Wolniewicz, Wydawnictwo Naukowe PWN, Warszawa 1997.

[78] WoŁynowicz T., Mój ostatni zachód słońca... A co potem?, Nasza Przyszłość, Bydgoszcz 1998.

[79] Yankelevitch V., Tajemnica śmierci i zjawisko śmierci, [in:] Antropologia śmierci. Myśl francuska, choosen and transl. by. S. Cichowicz, J.M. Godzimirski, Wydawnictwo Naukowe PWN, Warszawa 1993.

[80] Ziemba K., Jan Kochanowski jako poeta egzystencji, Towarzystwo „Ogród Ksiąg”, Warszawa 1994.

[81] Zwolıński A., Życie... ile razy?, Wydawnictwo WAM, Kraków 1998.

\section{ISTOTA NIEBEZPIECZEŃSTWA, CZYLI CYWILIZACYJNY KONTERFEKT PRZEMIJANIA}

Abstrakt. Artykuł przedstawia w szerokiej perspektywie różne stanowiska na przemijalność człowieka, dla którego piętnem i źródłem niebezpieczeństwa egzystencjalnego jest śmierć. Przyjęty w materiale sposób myślenia orientuje rozważania na czterech zasadniczych płaszczyznach, które tworzą filozofia, socjologia, psychologia, ale w głównej mierze bioetyka (a zwłaszcza tanatologia). W pewnym sensie tekst ma wymiar metafizyczny, gdzie ubytek bezpieczeństwa jest traktowany jako przypadłość mentalna zakorzeniona w społecznym odbiorze przemijania człowieka. Taki tryb rozumowania jest utwierdzony w tzw. koncepcji trupa, który staje się przejawem zrozumiałej dla ludzi ewolucji życia prowadzącej od stanu istnienia do niebytu. Uznanie martwoty za objaw porządku naturalnego jest paradoksem ludzkiej egzystencji utrwalonej w bogactwie myśli, projektów i nadziei. W opozycji do tego sposobu postrzegania trwałości (a raczej nietrwałości) życia w tekście zawarto stanowiska, które wykluczają przemijanie jako formę nieistnienia świadomości. Poglądy tego pokroju obudowane są stanowiskami obecnymi we współczesnej i otwartej na nowe zapatrywania medycynie (np. psychiatrii, onkologii, kardiologii czy psychologii). Z tej perspektywy artykuł jest nową na gruncie sekuritalnym propozycją badawczą. Słowa kluczowe: Nniebezpieczeństwo, śmierć, socjologia bezpieczeństwa, filozofia, cywilizacja, tanatologia. 
